\title{
Translation and cross-cultural adaptation of the Arizona Sexual Scale (ASEX) into Portuguese
}

\author{
Tradução e adaptação transcultural da Arizona Sexual Scale (ASEX) para a \\ língua portuguesa
}

\author{
Henrique Prata Ribeiro, ${ }^{1 *}$ (1) Inês Carreira Figueiredo, ${ }^{1,2 *}$ Joana Vitória-Silva, ${ }^{3}$ Pedro Barata, ${ }^{4}$ \\ Eduardo Palha Fernandes, ${ }^{5}$ Tiago Reis Marques ${ }^{2}$
}

\begin{abstract}
Introduction: Sexual dysfunction is common in individuals with psychiatric disorders and under psychotropic medication such as antidepressants and antipsychotics. Several scales have been developed to assess sexual function in these patients. The Arizona Sexual Scale (ASEX) is a five-item rating scale that quantifies sex drive, arousal, vaginal lubrication/penile erection, ability to reach orgasm, and satisfaction from orgasm. We describe the translation and cross-cultural adaptation of the ASEX into the Portuguese language, with the goal of contributing to the assessment of sexual function in Portuguese-speaking psychiatric patients under treatment with psychotropic drugs.

Methods: The translation and cross-cultural adaptation process thoroughly followed the steps recommended by the Task Force of the International Society for Pharmacoeconomics and Outcomes Research (ISPOR), namely: preparation, forward translation, reconciliation, back-translation, back-translation review, harmonization, cognitive debriefing, review of cognitive debriefing, finalization, proofreading, and final version.

Results: The process was successfully completed and no major differences were found between the translation, reconciliation and back-translation phases, with only small adjustments being made. Conclusion: The translation of the ASEX was completed successfully, following international reference guidelines. The use of these guidelines is a guarantee of a Portuguese version that is qualitatively and semantically equivalent to the original scale. This availability of this new scale version will enable studies evaluating the sexual function of Portuguese-speaking psychiatric patients. Future studies may assess the validity of the scale for Portuguese-speaking populations.

Keywords: Sexual dysfunction, ASEX, psychopharmacology, antipsychotic agents, antidepressive agents, schizophrenia, depression.
\end{abstract}

\section{Resumo}

Introdução: A disfunção sexual é comum em indivíduos com doenças psiquiátricas e sob o uso de medicações como antidepressivos e antipsicóticos. Várias escalas foram desenvolvidas para avaliar a função sexual desses doentes. A Arizona Sexual Scale (ASEX) é uma escala de cinco itens de avaliação que quantifica desejo sexual, excitação, lubrificação vaginal/ereção peniana, capacidade para atingir o orgasmo e satisfação com o orgasmo. Este artigo descreve o processo de tradução e adaptação transcultural da escala ASEX para a língua portuguesa, com o objetivo de contribuir para a avaliação da função sexual dos doentes medicados com fármacos psicotrópicos nos vários países onde se utiliza essa língua.

Métodos: A tradução e a adaptação transcultural seguiram de forma detalhada os passos recomendados pelo grupo de trabalho da International Society for Pharmacoeconomics and Outcomes Research (ISPOR), nomeadamente: preparação, tradução inicial, reconciliação, retroversão, revisão da retroversão, harmonização, teste cognitivo, revisão do teste cognitivo, finalização, leitura final e versão final.

Resultados: O processo foi completado com sucesso, e não foram observadas diferenças grandes entre as fases de tradução, reconciliação e retroversão, tendo sido feitos apenas pequenos ajustes.

Conclusão: A tradução da escala ASEX foi bem-sucedida, seguindo orientações internacionais de referência. A aplicação dessas orientações é a garantia de uma versão em língua portuguesa que é qualitativa e semanticamente equivalente à versão original da escala. A existência desta nova versão da escala permitirá estudos que avaliem a função sexual dos doentes em países nos quais se fale a língua portuguesa. Estudos futuros poderão atestar a validade da escala para essas populações. Descritores: Disfunção sexual, ASEX, psicofarmacologia, antipsicóticos, antidepressivos, esquizofrenia, depressão.

\footnotetext{
${ }^{1}$ Clínica 3, Centro Hospitalar Psiquiátrico de Lisboa, Lisboa, Portugal. ${ }^{2}$ Department of Psychosis studies, Institute of Psychiatry, Psychology and Neuroscience, King's College, London, UK. ${ }^{3}$ Hospital de Magalhães Lemos, Porto, Portugal. ${ }^{4}$ Hospital Professor Doutor Fernando Fonseca, Amadora, Portugal. ${ }^{5}$ Departamento de Psiquiatria e Saúde Mental, Unidade Local de Saúde do Alto Minho, Viana do Castelo, Portugal. * These authors have contributed equally to this manuscript. Submitted Jul 09 2018, accepted for publication Dec 132018.

Suggested citation: Prata Ribeiro H, Figueiredo IC, Vitória-Silva J, Barata P, Fernandes EP, Marques TR. Translation and cross-cultural adaptation of the Arizona Sexual Scale (ASEX) into Portuguese. Trends Psychiatry Psychother. 2019;41(3):247-253. http://dx.doi.org/10.1590/2237-6089-2018-0056
} 


\section{Introduction}

The concept of sexual dysfunction includes the multiple ways in which an individual is unable to participate in a sexual relationship as he or she would wish, as a result of impaired psychological and/or somatic processes - according to criteria from the International Classification of Diseases, 10th revision (ICD-10). ${ }^{1}$ It is common in individuals under the effect of psychopharmacological drugs, ${ }^{2-4}$ specifically occurring as an iatrogenic effect of selective serotonin reuptake inhibitors (SSRIs), reuptake inhibitors (SNRIs), ${ }^{5}$ and antipsychotics. ${ }^{6-8}$ It includes every aspect of sexual function, including desire, arousal, erection, ejaculation and orgasm. ${ }^{9}$ Although sexual dysfunction is common in psychiatric patients, its quantification is limited by several factors, such as relevant clinical information, time constraints and explicit sexual questions that could contribute to patient noncompliance. ${ }^{9}$ In clinical settings, the use of smaller and simpler questionnaires with clear and objective answers should be prioritized. However, there is a paucity of validated, user-friendly scales. ${ }^{9}$

The Arizona Sexual Scale (ASEX) is a five-item rating scale that quantifies sex drive, arousal, vaginal lubrication/penile erection, ability to reach orgasm, and satisfaction from orgasm. The total score ranges from 5 to 30 points, with higher scores indicating higher degrees of sexual dysfunction. ${ }^{9}$ This assessment tool was designed to be self- or clinician-administered, and it is adapted to either heterosexual or homosexual populations, regardless of the existence of a sexual partner. ${ }^{9}$ It is also validated for patients medicated with either antipsychotics ${ }^{10}$ or antidepressants, ${ }^{9}$ which is the target population in need of a more pertinent, expedient and less intrusive method of evaluating sexual dysfunction. ${ }^{9}$ Despite not covering all stages of sexual functioning, the ASEX is a simple and effective approach to determine and quantify sexual function impairment in psychiatric patients. ${ }^{10}$ Also, even though it is currently not possible to establish the etiology of sexual dysfunction, the ASEX has shown internal consistency, reliability, validity and sensitivity to accurately assess sexual dysfunction, if present. ${ }^{9}$ The ASEX has also been successfully used in the evaluation of particular populations, such as subjects with Parkinson's disease, ${ }^{11}$ epilepsy ${ }^{12}$ or undergoing dyalisis. ${ }^{13}$

Several studies have used ASEX to determine sexual functioning in psychotic patients. Uçok et al., using ASEX, concluded that $52.6 \%$ of patients with schizophrenia had sexual dysfunction, and that disease severity was correlated with the scale's total score. ${ }^{14}$

At the moment, the ASEX has only been translated into three other languages: Thai, ${ }^{15}$ French $^{16}$ and Arabic. ${ }^{17}$
In addition, very few related scales have been validated in the Portuguese language, and only very recently was the Sexual Function Questionnaire (SFQ) translated into Portuguese. ${ }^{18}$

In this study, we aim to describe the translation and validation process of the ASEX into the Portuguese language.

\section{Methods}

\section{Selection of research team and patients}

We enrolled 20 patients from Hospital de Magalhães Lemos, followed up at an outpatient clinic and receiving psychotropic medication, to perform the proofreading step of the scale translation process. All patients signed a written consent form before being involved in the translation process.

\section{Instrument: Arizona Sexual Experience Scale (ASEX)}

The ASEX measures each of its five items in a relatively nonintrusive bimodal fashion, using a 6-point Likert-type scale ranging from hyperfunction (1) to hypofunction (6). ${ }^{9}$ An open comment section is included for the expression of individual concerns and feedback. The male and female versions differ on the third question, which refers to penile erection or vaginal lubrication, accordingly. ${ }^{9}$ Three ASEX questions related to arousal, erection/lubrication, and ability to reach orgasm were adapted from previous work. ${ }^{19}$

\section{Procedures}

Translation procedures were carried out according to the guidelines of the Task Force for Translation and Cultural Adaptation of the International Society for Pharmacoeconomics and Outcomes Research (ISPOR). ${ }^{20}$

This methodology focuses on 10 steps to translate a scale:

1) Preparation: obtaining authorization from original authors and selecting translators.

2) Forward translation: production of two independent versions in Portuguese (translations 1 and 2).

3) Reconciliation: synthesis of translations 1 and 2.

4) Back-translation: performed by a translator who did not have previous contact with the other translators.

5) Back-translation review: comparison between the original and the new version of the scale.

6) Harmonization: assessment of discrepancies between different translations of the same instrument made prior to the translation process 
under way, with the objective of minimizing distinct results.

7) Cognitive debriefing: instrument application to a sample.

8) Review of cognitive debriefing results and finalization.

9) Proofreading.

10) Final report.

To follow this 10-step guidelines, we contacted the author of the original scale (step 1 ). Then, four translators with English proficiency were selected to participate in the translation process (step 2). Reconciliation of the scale was done using the first two translation versions (step 3), and a back-translation was made afterwards and compared to the original version (steps 4 and 5). The harmonization stage (step 6) was not possible to carry out, as no other languages had translations that would match the ISPOR criteria, making this the first translation to assure those principles. Cognitive debriefing (step 7) was completed by administering a compatible version of the scale to 20 psychiatric patients medicated with either antidepressants, antipsychotics or both. Informed consent was obtained in writing. Table 1 shows the cognitive debriefing questions used for patients and interviewers. After reviewing the results (step 8), the final version of the document was proofread by an expert in Portuguese-English translation (step 9). The final version of the translated scale is presented as an Appendix to this paper (step 10).

\section{Ethical considerations}

This study was approved by the ethics committee of Centro Hospitalar Psiquiátrico de Lisboa, Lisboa, Portugal.

\section{Results}

Table 2 presents examples of the original version of the scale, the initial translations, the result of the reconciliation stage, the back-translation and the final version - the latter was defined using both the initial translations and the back-translation (Escala ASEX ${ }^{\odot}$ ). No significant differences were found between translators in the third step of the translation.

From the total sample size of 20 patients who participated in the cognitive debriefing process, only one patient mentioned a relevant comment regarding the understanding of the scale. The authors opted to review the translation process as a whole, but no changes were made. This fact, added to the non-existence of other translations using the ISPOR guidelines, made the harmonization step impossible to perform.

\section{Discussion}

To our knowledge, this is the first study to describe the translation and cross-cultural adaptation of the

Table 1 - Questions used for cognitive debriefing of the Arizona Sexual Scale (ASEX)

\section{Questions asked to patients}

1. Can you understand every word of this question? If not, which is the word you don't understand?

2. Would you change anything in this question? If so, what would you and why?

3. Can you clearly understand what you are being asked? If not, why?

4. Do you consider the response options for this question adequate? If not, why?

\section{Question for collaborators}

Please suggest changes you think appropriate, based on the patient's opinions of the scale.

Table 2 - Translation process of the Arizona Sexual Scale (ASEX) from English into Portuguese

\begin{tabular}{|c|c|c|c|c|c|}
\hline Original & Translation 1 & Translation 2 & Reconciliation & Back-translation & Final version \\
\hline $\begin{array}{l}\text { How easily are you } \\
\text { sexually aroused } \\
\text { (turned on)? }\end{array}$ & $\begin{array}{l}\text { Com que } \\
\text { facilidade se excita } \\
\text { sexualmente? }\end{array}$ & $\begin{array}{l}\text { Quão facilmente se } \\
\text { excita sexualmente? }\end{array}$ & $\begin{array}{l}\text { Com que } \\
\text { facilidade se excita } \\
\text { sexualmente? }\end{array}$ & $\begin{array}{l}\text { How easily are you } \\
\text { sexually aroused? }\end{array}$ & $\begin{array}{l}\text { Com que } \\
\text { facilidade se excita } \\
\text { sexualmente? }\end{array}$ \\
\hline $\begin{array}{l}\text { For each item, } \\
\text { please indicate } \\
\text { your OVERALL level } \\
\text { during the PAST } \\
\text { WEEK, including } \\
\text { TODAY. }\end{array}$ & $\begin{array}{l}\text { Para cada item, } \\
\text { indique o seu nível } \\
\text { GERAL durante a } \\
\text { SEMANA PASSADA, } \\
\text { incluindo o dia de } \\
\text { HOJE. }\end{array}$ & $\begin{array}{l}\text { Para cada questão, } \\
\text { por favor indique o } \\
\text { nível GERAL durante } \\
\text { a ÚLTIMA SEMANA, } \\
\text { incluindo HOJE. }\end{array}$ & $\begin{array}{l}\text { Para cada questão, } \\
\text { por favor, indique o } \\
\text { seu nível GLOBAL } \\
\text { durante a SEMANA } \\
\text { PASSADA, incluindo } \\
\text { o dia de HOJE. }\end{array}$ & $\begin{array}{l}\text { For each item } \\
\text { indicate your } \\
\text { GLOBAL level } \\
\text { during LAST WEEK, } \\
\text { including TODAY. }\end{array}$ & $\begin{array}{l}\text { Para cada questão, } \\
\text { por favor, indique o } \\
\text { seu nível GLOBAL } \\
\text { durante a SEMANA } \\
\text { PASSADA, incluindo } \\
\text { o dia de HOJE. }\end{array}$ \\
\hline Very easily & Muito facilmente & Muito facilmente & Muito fácil & Very easily & Muito facilmente \\
\hline
\end{tabular}


ASEX to the Portuguese language. The translation was performed according to ISPOR criteria so that we could obtain a final version as accurate as possible. The use of this methodology warranted a solid final translation, as close to the original as possible, maintaining accuracy in the assessment of patients.

The ASEX is one of the scales most widely used for the assessment of sexual dysfunction in psychosis. We were only able to find three published translations of the English version of the scale, into Thai, ${ }^{15}$ French $^{16}$ and Arabic. ${ }^{17}$ Those translations, however, did not follow the ISPOR guidelines, and therefore the harmonization step was not performed.

The Portuguese version of the ASEX will be an important and useful instrument to assess the sexual function of patients who are under psychotropic medication. The final result (Escala ASEX ${ }^{\odot}$ ) is presented in this article as an Appendix.

With regard to limitations, the main one was the unavailability of other ISPOR-compliant translations, which prevented the harmonization step from being performed.

\section{Conclusions}

The original version of the ASEX was translated into Portuguese according to ISPOR guidelines. Using the ISPOR guidelines allowed us to obtain a reliable version of the scale that will be validated for use in the Portuguese population by the same authors. The scale may now be used to assess the sexual function in psychiatric patients under psychopharmacological treatment. This tool is of utmost importance, as there are only very few suitable scales for this particular population.

\section{Acknowledgments}

We thank João Oliveira Pratas and Teresa Leal for contributing to the translation process.

\section{Disclosure}

Henrique Prata Ribeiro has received personal fees from Angelini Farmacêutica and non-financial support from Janssen-Cilag, Lundeck Portugal, and Tecnifar Portugal. Tiago Reis Marques has received personal fees from Lundbeck and Pfizer. No other conflicts of interest declared concerning the publication of this article.

\section{References}

1. American Psychiatric Association. Diagnostic and Statistical Manual of Mental Disorders, Fifth Edition (DSM-5). Arlington: American Psychiatric Publishing; 2013.

2. Montejo L, Angel L, Navarro-Cremades F. Sexual side-effects of antidepressant and antipsychotic drugs. Curr Opin Psychiatr. 2015;28:418-23.

3. La Torre A, Giupponi G, Duff DM, Pompili M, Grözinger M, Kapfhammer HP, et al. Sexual dysfunction related to psychotropic drugs: a critical review. Part III: mood stabilizers and anxiolytic drugs. Pharmacopsychiatry. 2014;47:1-6.

4. La Torre A, Giupponi G, Duff DM, Pompili M, Grözinger M, Kapfhammer HP, et al. Sexual dysfunction related to psychotropic drugs: a critical review part II: antipsychotics. Pharmacopsychiatry. 2013;46:201-8.

6. Zink M, Englisch S. Schizophrenia treatment: an obstacle course. Lancet Psychiatry. 2016;3.4:310-2.

5. Otte C, Gold SM, Penninx BW, Pariante CM, Etkin A, Fava M, et al. Major depressive disorder. Nat Rev Dis Primers. 2016:2:160-5.

7. Montejo AL, Majadas S, Rico-Villademoros F, Llorca G, De La Gándara J, Franco M, et al. Frequency of sexual dysfunction in patients with a psychotic disorder receiving antipsychotics. J Sex Med. 2010;7:3404-13.

8. Serretti A, Chiesa A. A meta-analysis of sexual dysfunction in psychiatric patients taking antipsychotics. Int Clin Psychopharmacol. 2011;26:130-40.

9. McGahuey CA, Gelenberg AJ, Laukes CA, Moreno FA, Delgado PL, McKnight KM, et al. The Arizona Sexual Experience Scale (ASEX): reliability and validity. J Sex Marital Ther. 2000;26:25-40.

10. De Boer M, Castelein S, Wiersma D, Schoevers RA, Knegtering H. A systematic review of instruments to measure sexual functioning in patients using antipsychotics. J Sex Res. 2014;51:383-9.

11. Kaya Y, Ozer F, Benli E, Yilmaz NH, Aydemir T, Demir EY. Evaluation of sexual dysfunction in Parkinson's disease between two different regions of Turkey. Clin Neurol Neurosurg. 2017;161:117-20.

12. Ogunjimi L, Yaria J, Makanjuola A, Ogunniyi A. Sexual dysfunction among Nigerian women with epilepsy. Epilepsy Behav. 2018;83:108-12.

13. Hekmat R, Maghsudloo F, Mohebi M, Rezaee SA, Vakili R, Panah HR. A study of the main determinants of sexual dysfunction in women aged $15-45$ years on chronic hemodialysis. Saudi J Kidney Dis Transpl. 2016;27:916-20.

14. Uçok $A$, Incesu $C$, Aker T, Erkoç $S$. Sexual dysfunction in patients with schizophrenia on antipsychotic medication. Eur Psychiatry. 2007;22:328-33.

15. Jitkritsadakul O, Jagota $P$, Bhidayasiri R. The Arizona sexual experiences scale: a validity and reliability assessment of the Tha translation (ASEX-Thai) in Parkinson's disease. J Parkinsons Dis. 2014;4:205-10.

16. Briki M, Haffen E, Monnin J, Tio G, Nicolier M, Sechter D, Vande P. Sexual dysfunction and depression: Validity of a French version of the ASEX scale. Encephale. 2014;40:114-22.

17. Nakhli J, El Kissi Y, Bouhlel S, Amamou B, Nabli TA, Nasr SB, et al. Reliability and validity of the Arizona Sexual Experiences ScaleArabic version in Tunisian patients with schizophrenia. Compr Psychiatry. 2014;55:1473-7.

18. Lapa CO, Rocha GP, Marques TR, Howes O, Smith S, Monteiro RT, et al. Translation and cross-cultural adaptation of the Sexual Function Questionnaire (SFQ) into Brazilian Portuguese. Trends Psychiatry Psychother. 2017;39:110-5.

19. Prisant LM, Carr AA, Bottini PB, PharmD, et al. Sexual dysfunction with antihypertensive drugs. Arch Intern Med. 1994;154:730-6.

20. Wild D, Grove A, Martin M, Eremenco S, McElroy S, VerjeeLorenz A, et al. ISPOR Task Force for Translation and Cultura Adaptation. Principles of Good Practice for the Translation and Cultural Adaptation Process for Patient-Reported Outcomes (PRO) Measures: report of the ISPOR Task Force for Translation and Cultural Adaptation. Value Health. 2005;8:94-104.

\section{Correspondence:}

Henrique Prata Ribeiro

Avenida do Brasil, 53

1749-002 - Lisboa - Portugal

Tel. : +351916960508

E-mail: henriqueprata@gmail.com 


\section{Appendix - Final version of the Arizona Sexual Scale (ASEX) in Portuguese}

\section{Escala ASEX@}

Instruções gerais para clínicos que utilizem a escala

A escala ASEX destina-se a todos os doentes que participem no estudo, independentemente do seu nível de actividade sexual ou método de prática sexual.

Deve haver uma discussão geral na primeira utilização da escala. Esta discussão deve incluir a comunicação de que, apesar do estado actual do nível de actividade sexual, gostaria que preenchessem a escala. Por favor, explicite que inclui tanto actividade sexual com parceiro como masturbação. Não é necessário que o doente explique a sua preferência ou prática actual.

Se o doente não for sexualmente activo e não tiver desejo de actividade sexual, deve ser encorajado a preencher a escala, visto essa informação ser avaliada por pontuações consistentes de 5 e 6 em cada item.

\section{Instruções globais para auto-avaliação - ASEX \\ Formulário de instruções para o indivíduo}

A ASEX deve ser completada por todos os participantes do estudo, independentemente da frequência da sua actividade sexual ou do tipo de prática sexual. A actividade sexual inclui com parceiro ou masturbação. É incentivado a completar todas as questões, mesmo que não seja sexualmente activo ou que não tenha desejo de actividade sexual. Os comentários podem ser incluídos no final da escala.

\section{Escala de Experiências Sexuais de Arizona - ASEX \\ Métodos de pontuação}

A Escala de Experiências sexuais de Arizona (ASEX) pode ser utilizada para identificar indivíduos que padeçam de disfunção sexual. A ASEX é uma escala pontuada pelo doente.

A escala ASEX destina-se a aquisição de informação quantitativa, relativa ao funcionamento sexual em cinco áreas específicas. Os seguintes parâmetros ajudam a interpretar as classificações da ASEX ${ }^{\odot}$ :

A pontuação média para adultos (doentes e controlos) com disfunção sexual clínica é 21 nas mulheres e 20 nos homens.

A pontuação média para adultos (doentes e controlos) sem disfunção sexual clínica é de 14 nas mulheres e 10 nos homens.

A análise ROC (Característica de Recepção do Operador) revelou um valor de área sob a curva (AUC) de 0,929 + 0,029, indicando excelente sensibilidade e especificidade da ASEX na identificação de disfunção sexual.

Os critérios-alvo enumerados abaixo oferecem uma orientação na pontuação representativa das fortes sensibilidade e especificidade da ASEX:

\section{Pontuação total ASEX $\geq 19$ \\ Ou}

Qualquer item com pontuação individual de $\geq 5$

Ou

Quaisquer 3 itens com uma pontuação individual de $\geq 4$

Estão altamente correlacionados com a presença de disfunção sexual diagnosticada por um clínico.

As pontuações totais ASEX variam de um mínimo de 5 a um máximo de 30 . 
ESCALA DE EXPERIÊNCIA SEXUAL DE ARIZONA

$(\text { ASEX) })^{\odot}-$ MASCULINO

Para cada questão, por favor, indique o seu nível GLOBAL durante a SEMANA PASSADA, incluindo o dia de HOJE.

\section{Qual é a intensidade do seu impulso sexual?}

$\begin{array}{llllll}1 \square & 2 \square & 3 \square & 4 \square & 5 \square & 6 \square \\ \text { extremamente } & \text { muito } & \text { relativamente } & \text { relativamente } & \text { muito } & \text { sem impulso sexual } \\ \text { forte } & \text { forte } & \text { forte } & \text { fraco } & \text { fraco } & \end{array}$

\section{Com que facilidade se excita sexualmente?}

\begin{tabular}{|c|c|c|c|c|c|}
\hline $\begin{array}{l}1 \square \\
\text { extremamente } \\
\text { fácil }\end{array}$ & $\begin{array}{l}2 \square \\
\text { muito } \\
\text { fácil }\end{array}$ & $\begin{array}{l}3 \square \\
\text { relativamente } \\
\text { fácil }\end{array}$ & $\begin{array}{l}4 \square \\
\text { relativamente } \\
\text { difícil }\end{array}$ & $\begin{array}{l}5 \square \\
\text { muito } \\
\text { difícil }\end{array}$ & $\begin{array}{l}6 \\
\text { nunca me excito }\end{array}$ \\
\hline
\end{tabular}

3. Consegue, facilmente, alcançar e manter uma ereção?

\begin{tabular}{|c|c|c|c|c|c|}
\hline $1 \square$ & $2 \square$ & $3 \square$ & $4 \square$ & $5 \square$ & $6 \square$ \\
\hline $\begin{array}{l}\text { extremamente } \\
\text { fácil }\end{array}$ & $\begin{array}{l}\text { muito } \\
\text { fácil }\end{array}$ & $\begin{array}{l}\text { relativamente } \\
\text { fácil }\end{array}$ & $\begin{array}{l}\text { relativamente } \\
\text { difícil }\end{array}$ & $\begin{array}{l}\text { muito } \\
\text { difícil }\end{array}$ & nunca me excito \\
\hline
\end{tabular}

\section{Com que facilidade atinge o orgasmo?}

$\begin{array}{llllll}1 \square & 2 \square & 3 \square & 4 \square & 5 \square & 6 \square \\ \text { extremamente } & \text { muito } & \text { relativamente } & \text { relativamente } & \text { muito } & \text { nunca me excito } \\ \text { fácil } & \text { fácil } & \text { fácil } & \text { difícil }\end{array}$

\section{Os seus orgasmos são compensadores?}

\begin{tabular}{|c|c|c|c|c|c|}
\hline$\square$ & $2 \square$ & $3 \square$ & $4 \square$ & $5 \square$ & $6 \square$ \\
\hline $\begin{array}{l}\text { pastante } \\
\text { compensadores }\end{array}$ & $\begin{array}{l}\text { muito } \\
\text { compensadores }\end{array}$ & $\begin{array}{l}\text { relativamente } \\
\text { compensadores }\end{array}$ & $\begin{array}{l}\text { algo } \\
\text { insatisfatórios }\end{array}$ & $\begin{array}{l}\text { muito } \\
\text { insatisfatórios }\end{array}$ & $\begin{array}{l}\text { não consigo alcançar } \\
\text { atingir o orgasmo }\end{array}$ \\
\hline
\end{tabular}

\section{COMENTÁRIOS:}


ESCALA DE EXPERIÊNCIA SEXUAL DE ARIZONA

(ASEX) $^{\odot}$ - FEMININO

Para cada questão, por favor, indique o seu nível GLOBAL durante a SEMANA PASSADA, incluindo o dia de HOJE.

\section{Qual é a intensidade do seu impulso sexual?}

$\begin{array}{llllll}1 \square & 2 \square & 3 \square & 4 \square & 5 \square & 6 \square \\ \text { extremamente } & \text { muito } & \text { relativamente } & \text { relativamente } & \text { muito } & \text { sem impulso sexual } \\ \text { forte } & \text { forte } & \text { forte } & \text { fraco } & \text { fraco } & \end{array}$

\section{Com que facilidade se excita sexualmente?}

\begin{tabular}{|c|c|c|c|c|c|}
\hline $1 \square$ & $2 \square$ & $3 \square$ & $4 \square$ & $5 \square$ & $6 \square$ \\
\hline $\begin{array}{l}\text { extremamente } \\
\text { fácil }\end{array}$ & $\begin{array}{l}\text { muito } \\
\text { fácil }\end{array}$ & $\begin{array}{l}\text { relativamente } \\
\text { fácil }\end{array}$ & $\begin{array}{l}\text { relativamente } \\
\text { difícil }\end{array}$ & $\begin{array}{l}\text { muito } \\
\text { difícil }\end{array}$ & ne excito \\
\hline
\end{tabular}

3. Does your vagina get moist or wet during sexual intercourse?

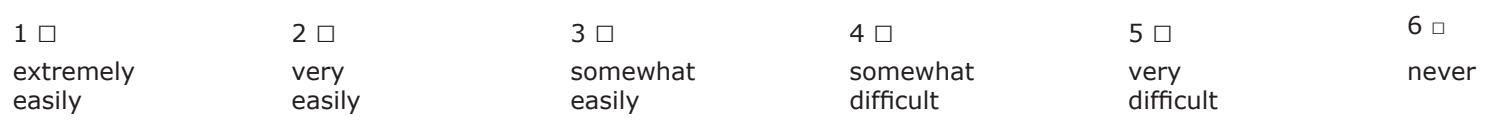

\section{Com que facilidade atinge o orgasmo?}

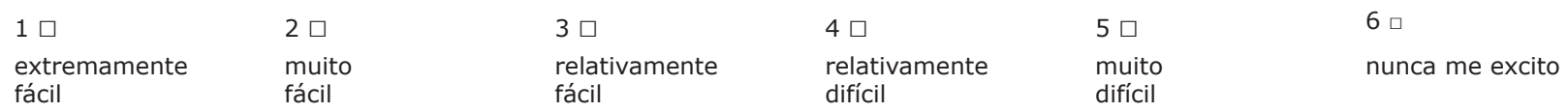

\section{Os seus orgasmos são compensadores?}

\begin{tabular}{|c|c|c|c|c|c|}
\hline$\square$ & $2 \square$ & $3 \square$ & $4 \square$ & $5 \square$ & $6 \square$ \\
\hline $\begin{array}{l}\text { pastante } \\
\text { compensadores }\end{array}$ & $\begin{array}{l}\text { muito } \\
\text { compensadores }\end{array}$ & $\begin{array}{l}\text { relativamente } \\
\text { compensadores }\end{array}$ & $\begin{array}{l}\text { algo } \\
\text { insatisfatórios }\end{array}$ & $\begin{array}{l}\text { muito } \\
\text { insatisfatórios }\end{array}$ & $\begin{array}{l}\text { não consigo alcançar } \\
\text { atingir o orgasmo }\end{array}$ \\
\hline
\end{tabular}

\section{COMENTÁRIOS:}


http://dx.doi.org/10.1590/2237-6089-2022-0003

The authors of the article entitled "Translation and cross-cultural adaptation of the Arizona Sexual Scale (ASEX) into Portuguese" (doi: http://dx.doi.org/10.1590/2237-6089-2018-0056), published in Trends in Psychiatry and Psychotherapy in volume 41 (2019), issue 3, pages 247-253, would like to correct an error in the Appendix, namely, on page 253, question no. 3 of the female version of the scale is shown in English, when instead it should be shown in Portuguese. Below we reproduce the correct version of this part of the scale.

\section{ESCALA DE EXPERIÊNCIA SEXUAL DE ARIZONA \\ $(A S E X)^{\odot}-$ FEMININO}

Para cada questão, por favor, indique o seu nível GLOBAL durante a SEMANA PASSADA, incluindo o dia de HOJE.

\section{Qual é a intensidade do seu impulso sexual?}

$\begin{array}{llllll}1 \square & 2 \square & 3 \square & 4 \square & 5 \square & 6 \square \\ \text { extremamente } & \text { muito } & \text { relativamente } & \text { relativamente } & \text { muito } & \text { sem impulso sexual } \\ \text { forte } & \text { forte } & \text { forte } & \text { fraco } & \text { fraco } & \end{array}$

\section{Com que facilidade se excita sexualmente?}

$\begin{array}{llllll}1 \square & 2 \square & 3 \square & 4 \square & 5 \square & 6 \square \\ \text { extremamente } & \text { muito } & \text { relativamente } & \text { relativamente } & \text { muito } & \text { nunca me excito } \\ \text { fácil } & \text { fácil } & \text { fácil } & \text { difícil } & \text { difícil } & \end{array}$

3. Com que facilidade a sua vagina lubrifica durante o acto sexual?

\begin{tabular}{|c|c|c|c|c|c|}
\hline $1 \square$ & $2 \square$ & $3 \square$ & $4 \square$ & $5 \square$ & $6 \square$ \\
\hline $\begin{array}{l}\text { extremamente } \\
\text { fácil }\end{array}$ & $\begin{array}{l}\text { muito } \\
\text { fácil }\end{array}$ & $\begin{array}{l}\text { relativamente } \\
\text { fácil }\end{array}$ & $\begin{array}{l}\text { relativamente } \\
\text { difícil }\end{array}$ & $\begin{array}{l}\text { muito } \\
\text { difícil }\end{array}$ & nunca \\
\hline
\end{tabular}

\section{Com que facilidade atinge o orgasmo?}

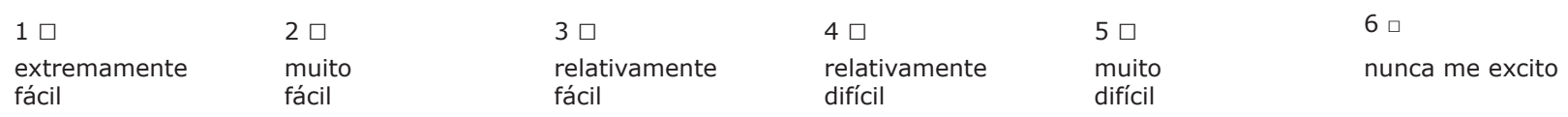

\section{Os seus orgasmos são compensadores?}

\begin{tabular}{|c|c|c|c|c|c|}
\hline $1 \square$ & $2 \square$ & $3 \square$ & $4 \square$ & $5 \square$ & 6 口 \\
\hline $\begin{array}{l}\text { astante } \\
\text { ompensadores }\end{array}$ & $\begin{array}{l}\text { muito } \\
\text { compensadores }\end{array}$ & $\begin{array}{l}\text { relativamente } \\
\text { compensadores }\end{array}$ & $\begin{array}{l}\text { algo } \\
\text { insatisfatórios }\end{array}$ & $\begin{array}{l}\text { muito } \\
\text { insatisfatórios }\end{array}$ & $\begin{array}{l}\text { não consigo alcançar } \\
\text { atingir o orgasmo }\end{array}$ \\
\hline
\end{tabular}

\section{COMENTÁRIOS:}

